\title{
ZARYS ŚRODOWISK SEDYMENTACYJNYCH W DOLINIE ANTHEMOUSA (PÓLNOCNA GRECJA). WSTĘPNE WYNIKI BADAŃ GEOARCHEOLOGICZNYCH W RAMACH PROJEKTU ANTHEMOUS VALLEY ARCHAEOLOGICAL PROJECT
}

\author{
AN OUTLINE OF SEDIMENTARY ENVIRONMENTS \\ IN THE ANTHEMOUS VALLEY (NORTHERN GREECE). \\ PRELIMINARY RESULTS OF GEOARCHAEOLOGICAL \\ RESEARCH UNDER THE ANTHEMOUS VALLEY \\ ARCHAEOLOGICAL PROJECT
}

\author{
Jakub Niebieszczański \\ Instytut Archeologii, Wydział Historyczny, Uniwersytet im. Adama Mickiewicza \\ ul. Umultowska 89D, 61-614 Poznań, Poland \\ jakubniebieszczanski@gmail.com
}

\begin{abstract}
This paper provides an overview of the first results of the Anthemous Valley Archaeological Project II, financed by the Polish National Science Centre (grant: 2013/09/N/HS3/ /01092). The aim of the project is to reconstruct the former landscapes of the alluvial Anthemous Valley in Northern Greece, near Thessaloniki City, in the light of archaeological and palaeogeographical data. The paper presents the results of two field surveys, which were conducted in 2013 and 2014 in order to gain a general understanding of the diversity of sedimentary environments in the valley in a wider context. Some palaeogeographical observations are also given.

KEY WORDS: Central Macedonia, Northern Greece, Northern Aegean Neolithic, Northern Aegean Bronze Age, Thermaic Bay, Thessaloniki Bay, Thessaloniki Plain, Anthemous Valley, Anthemountas Valley, Geoarchaeology, Alluvial Valleys, Buried Archaeology
\end{abstract}




\section{WSTĘP, STAN I CEL BADAŃ}

Dolina Anthemousa leży w zachodniej części Półwyspu Chalcydyckiego w bliskim sąsiedztwie Salonik (Thessaloniki) w centralnej Macedonii ${ }^{1}$. Zlewnia zajmuje obszar ponad $440 \mathrm{~km}^{2}$, a rzeka Anthemous wykorzystuje dolinę o przebiegu równoleżnikowym. Źródła cieku znajdują się u podnóży masywu Cholomondas, a uchodzi on do Zatoki Termajskiej (ryc. 1). Obecnie płaskie dno doliny służy jako zaplecze żywnościowe i magazynowe dla Salonik, dzięki polom uprawnym i strefom ekonomicznym.

Ludzka obecność w dolinie sięga okresu środkowego neolitu (7800/7600 BP; Andreou i in. 2016). Pozostałości archeologiczne widoczne są w wielu miejscach, zwłaszcza formy krajobrazowe, takie jak tumby z epoki brązu czy trapezy z wczesnej epoki żelaza. Obecnie kontekst środowiskowy stanowisk archeologicznych jest znacznie przekształcony przez działalność rolniczą. Główna rzeka odwadniająca obszar płynie częściowo w betonowym korycie, a jej przepływ uzależniony jest od okresów wzmożonych opadów.

W XX w. zostało przeprowadzonych kilka rekonesansów i opracowań archeologicznych doliny Anthemousa o różnym stopniu dokładności zarówno przestrzennej, jak i czasowej. Pierwsze wzmianki o dolinie znalazły się w katalogach Rey'a i Huertley'a w ramach prac Szkoły Brytyjskiej w Atenach w pierwszej połowie ubiegłego wieku (Rey 1917; Heurtley 1939). Dotyczyły one lokalizacji i generalnej chronologii stanowisk w Macedonii. Podobne opracowanie powstało w latach sześćdziesiątych, którego autorem był D.H. French (1967). W latach dziewięćdziesiątych XX w. powstała również praca D. Grammenosa, M. Besiosa i K. Kotsosa, w której autorzy przedstawili wyniki wykopalisk przeprowadzonych na wybranych stanowiskach w dolinie (Grammenos i in. 1997). Autorzy powyższych prac nie uwzględnili jednak wszystkich stanowisk pradziejowych znajdujących się w dolinie Anthemousa. Od lat siedemdziesiątych XX w. rozkwit inwestycyjny w Grecji i towarzyszące mu archeologiczne badania ratownicze przyniosły nowe informacje dotyczące osadnictwa $\mathrm{w}$ dolinie (Andreou $\mathrm{i}$ in. 2001). Od $2011 \mathrm{r}$. są prowadzone badania w ramach Anthemous Valley Archaeological Project (Andreou i in. 2016), których celem jest pozyskanie dokładnej informacji o lokalizacji znanych stanowisk, ich zasięgu, chronologii, relacji przestrzennych i poszukiwanie nowych stanowisk, a w efekcie opracowanie modelu osadnictwa pradziejowego $\mathrm{w}$ dolinie.

Celem artykułu jest przedstawienie ogólnych informacji i wstępnych wyników badań projektu Anthemous Valley Archaeological Project II (dalej AVAP II) ${ }^{2}$, dotyczącego dynamiki procesów kształtujących dolinę na przestrzeni ostatnich 12000 lat.

\footnotetext{
${ }^{1}$ Macedonia w ujęciu północnej Grecji.

${ }^{2}$ Projekt finansowany przez NCN, nr projektu: 2013/09/N/HS3/01092, w ramach programu PRELUDIUM.
} 


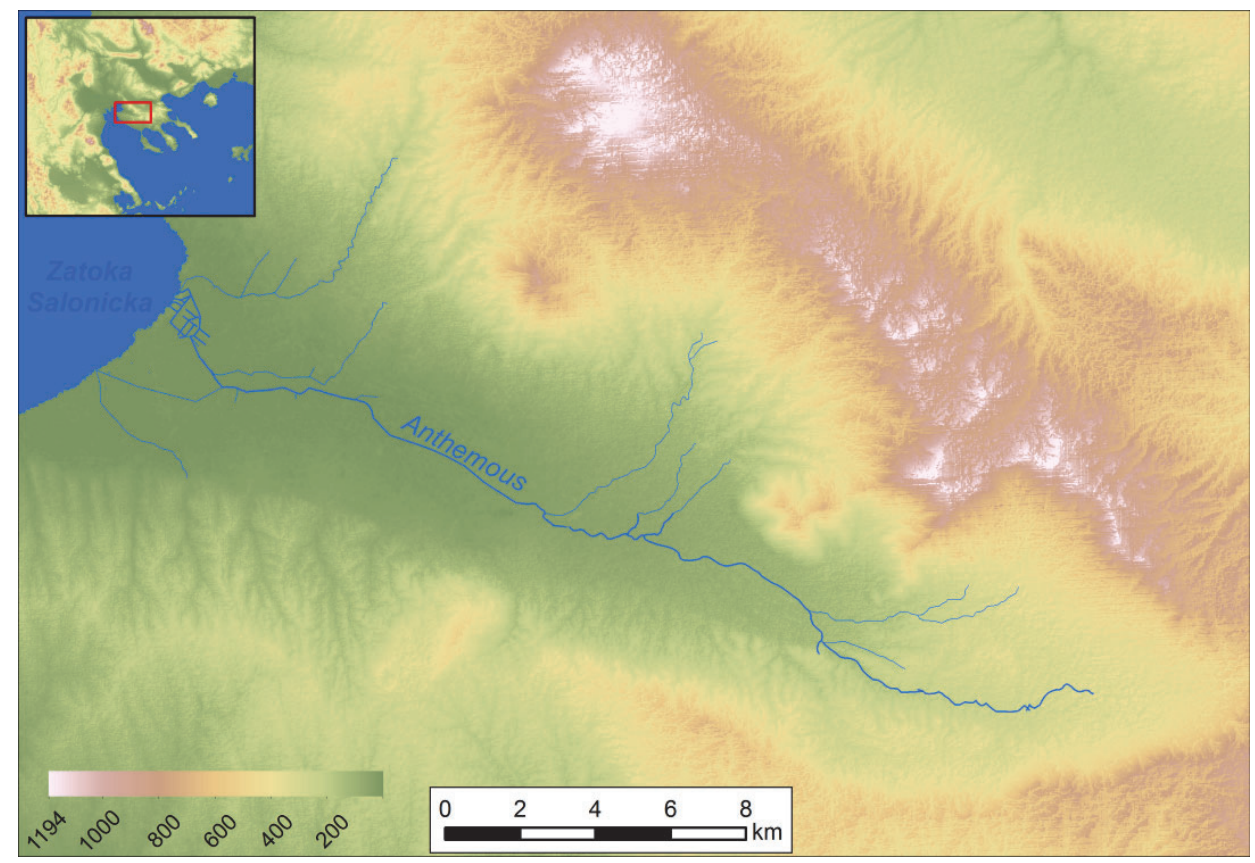

Ryc. 1. Obszar badań, dolina Anthemousa, Płw. Chalkidiki, Grecja północna

Fig. 1. Study area. Anthemous river valley, Chalkidikie Peninsula, Northern Greece

Niniejszy tekst jest rozwinięciem opublikowanego w języku angielskim artykułu dotyczącego wstępnych wyników projektu badań geoarcheologicznych w dolinie Anthemousa (Niebieszczański 2016).

\section{Kontekst środowiskowy}

Dolina Anthemousa zlokalizowana jest w strefie uskoku tektonicznego Anthemousa (ryc. 2) (Raspini i in. 2013, 2426). Oddziela on Pas Circumrodopski z masywem Chortiatisu na północy od Strefy Wardaru (Axiosu) na południu. Między nimi powstało skrzydło wiszące uskoku, którego strop tworzy płaskie dno doliny (Kockel, Mollat 1978; Mountrakis i in. 2006, s. 660-661; Kazakis i in. 2013). Północne zbocza doliny, które miejscami osiągają 1900 m n.p.m., zbudowane są głównie ze skał mezozoicznych, takich jak gabra, lupki czy granodioryty. Ponadto występują tam również skały głębinowe, takie jak perydotyty czy dunity, a także metamorficzne serpentynity z licznymi żyłami magnezytowymi (Kockel, Mollat 1978). Południowe zbocza o wiele niższe i łagodniejsze niż przeciwległe tworzą głównie neogeńskie skały osadowe zalegające na jurajskich skałach osadowych będących 
częścią Strefy Geotektonicznej Wardaru-Axiosu (Zervopolou i in. 2007, s. 3). Na dnie doliny zdeponowana jest miąższa seria osadów czwartorzędowych, w którą głęboko wcięte jest współczesne koryto rzeki. W osadach czwartorzędowych w wielu miejscach wycięte są strome krawędzie ciągnące się wzdłuż doliny i zbudowane $\mathrm{z}$ różnoziarnistego materiału.
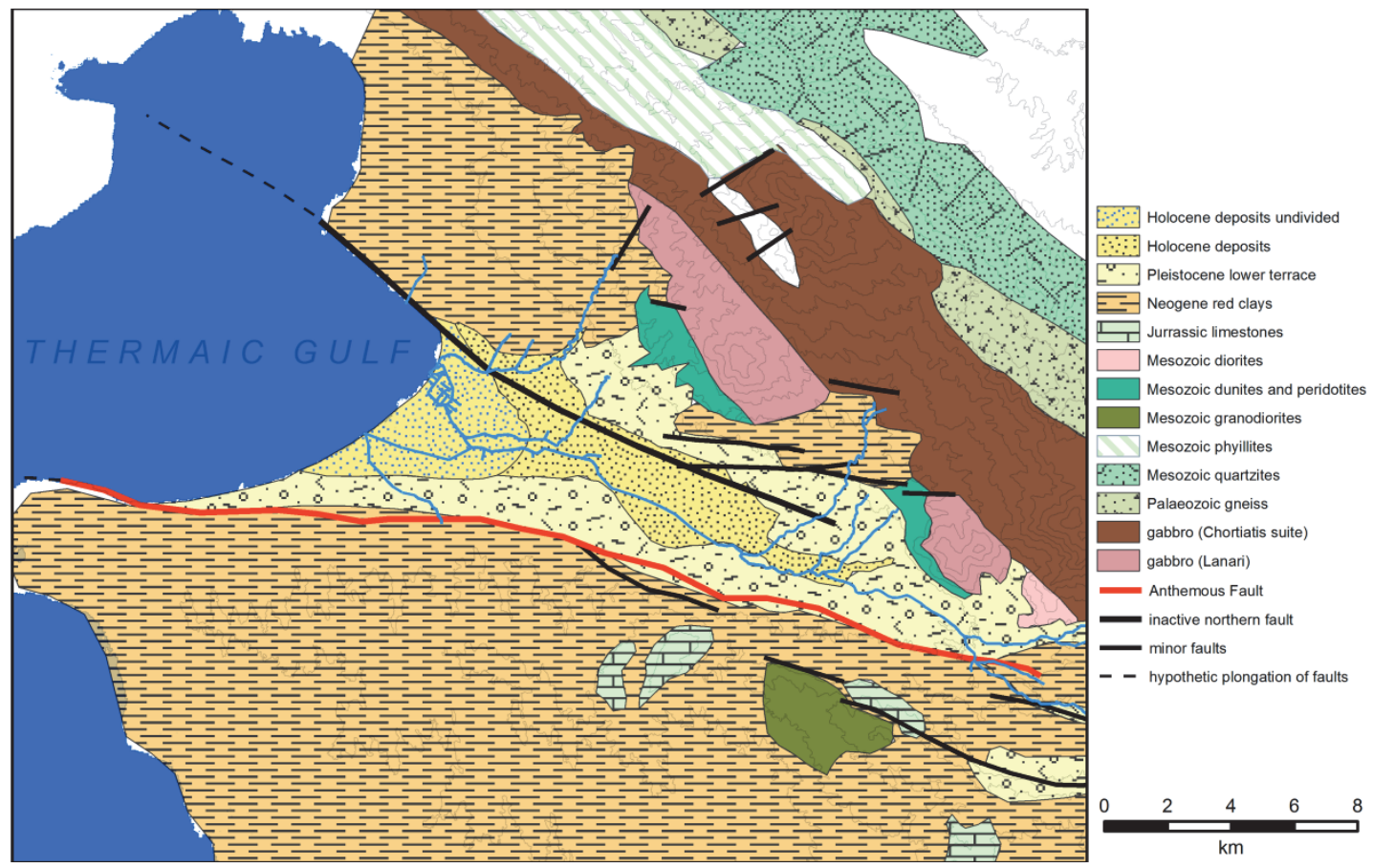

Ryc. 2. Mapa geologiczna obszaru badań. Opracowano na podstawie Kockel, Mollat 1978 i Mountrakis et al. 2006

Fig. 2. Study area geological map. After: Kockel, Mollat 1978 and Mountrakis et al. 2006

Geomorfologicznie dolinę można dzielić na cztery pasy na podstawie genezy, spadków terenu i wysokości bezwzględnej (ryc. 3). Pierwszy pas tworzą zbocza doliny, z cienką warstwą pokrywy zwietrzelinowej lub jej częściowym brakiem. Obserwuje się wyraźną różnicę w nachyleniu terenu między zboczami północnymi a południowymi. Pierwsze, będące częścią masywu górskiego, charakteryzują się nachyleniem średnio pomiędzy $20^{\circ}$ a $30^{\circ}$, z kolei południowe, łagodniejsze, zawierają się $\mathrm{w}$ przedziale $10-20^{\circ}$. Niżej położona jest neogeńska i plejstoceńska terasa z licznymi (zwłaszcza po południowej stronie doliny) stożkami napływowymi (Kockel $i$ in. 1978), tworząca drugi pas tzw. przejściowy. Kolejnym jest płaskie dno doliny 


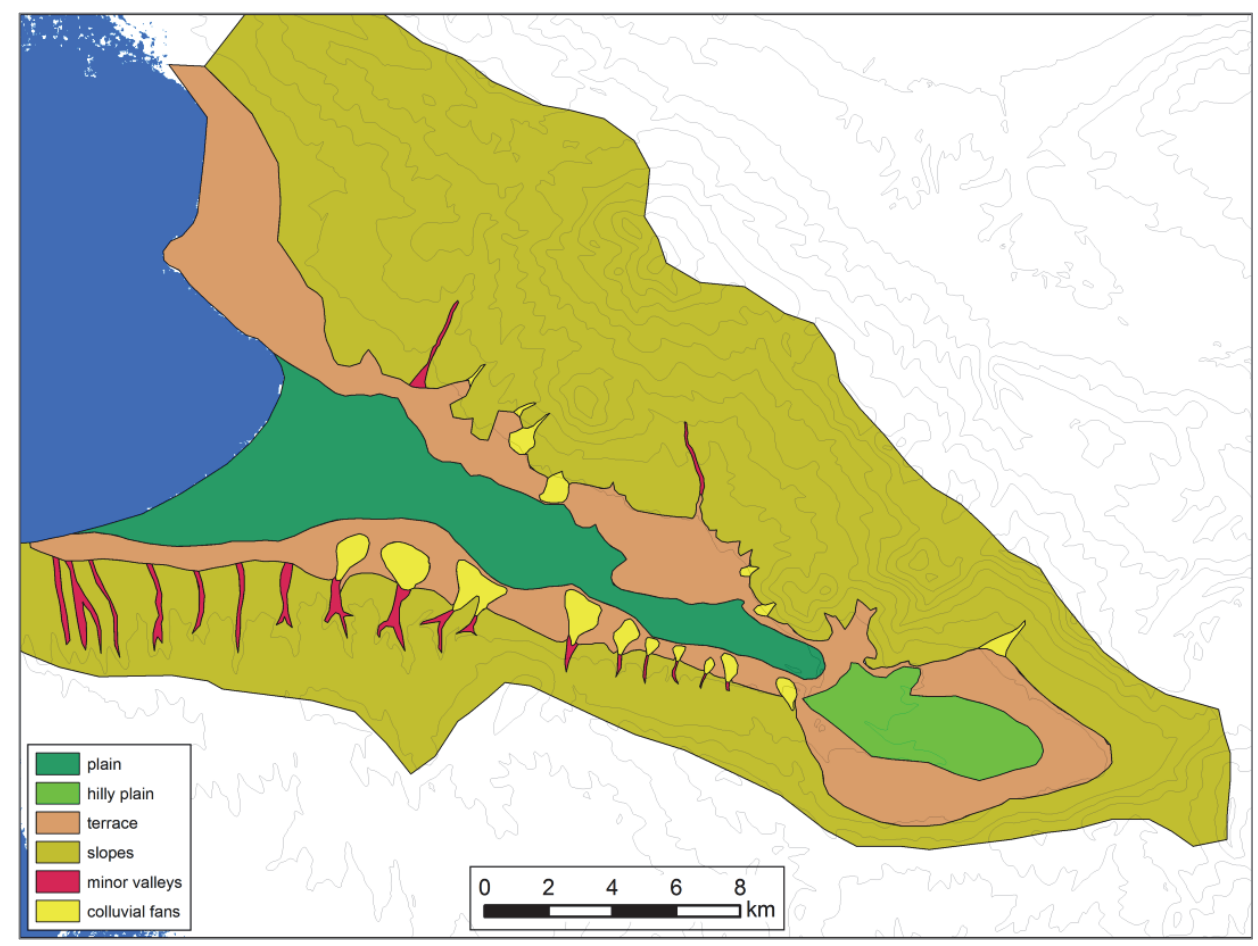

Ryc. 3. Rzeźba terenu obszaru badań

Fig. 3. Relief of study area

zbudowane z holoceńskich aluwiów o wysokości bezwzględnej nieprzekraczającej 100 m n.p.m., która tworzy dolny basen (ryc. 4, ryc. 5, ryc. 6). Dno doliny w części wschodniej o bardziej urozmaiconej rzeźbie i zazębiających się osadach stokowych i aluwialnych stanowi ostatni pas - basen górny (ryc. 4 , ryc. 5 , ryc. 7). Baseny te charakteryzują się słabym nachyleniem terenu, nieprzekraczającym $10^{\circ}$ i oddzielone są od siebie wypiętrzeniem skał ofiolitowych o wysokości względnej ok. $100 \mathrm{~m}$, który jest zarazem barierą dzielącą dwie jednostki hydrogeologiczne - system wód podziemnych Galatista (basen górny) oraz Vasilika (basen dolny) (Kazakis i in. 2013: ryc. 8).

Głównym ciekiem odwadniającym obszar jest rzeka Anthemous. Obecnie jest to ciek okresowy (płynie jedynie w okresie zimowym i wiosennym), który latem epizodycznie prowadzi wodę $\mathrm{w}$ uregulowanym i skanalizowanym korycie podczas intensywniejszych opadów. Duża część wód wykorzystywana jest w ramach systemów nawadniających pola uprawne, dlatego też w okresach wzmożonej aktywności rolniczej koryto jest suche. Anthemous zasilany jest ponadto kilkoma mniejszymi strumieniami spływającymi ze zboczy doliny w jej środkowym i dolnym odcinku. 

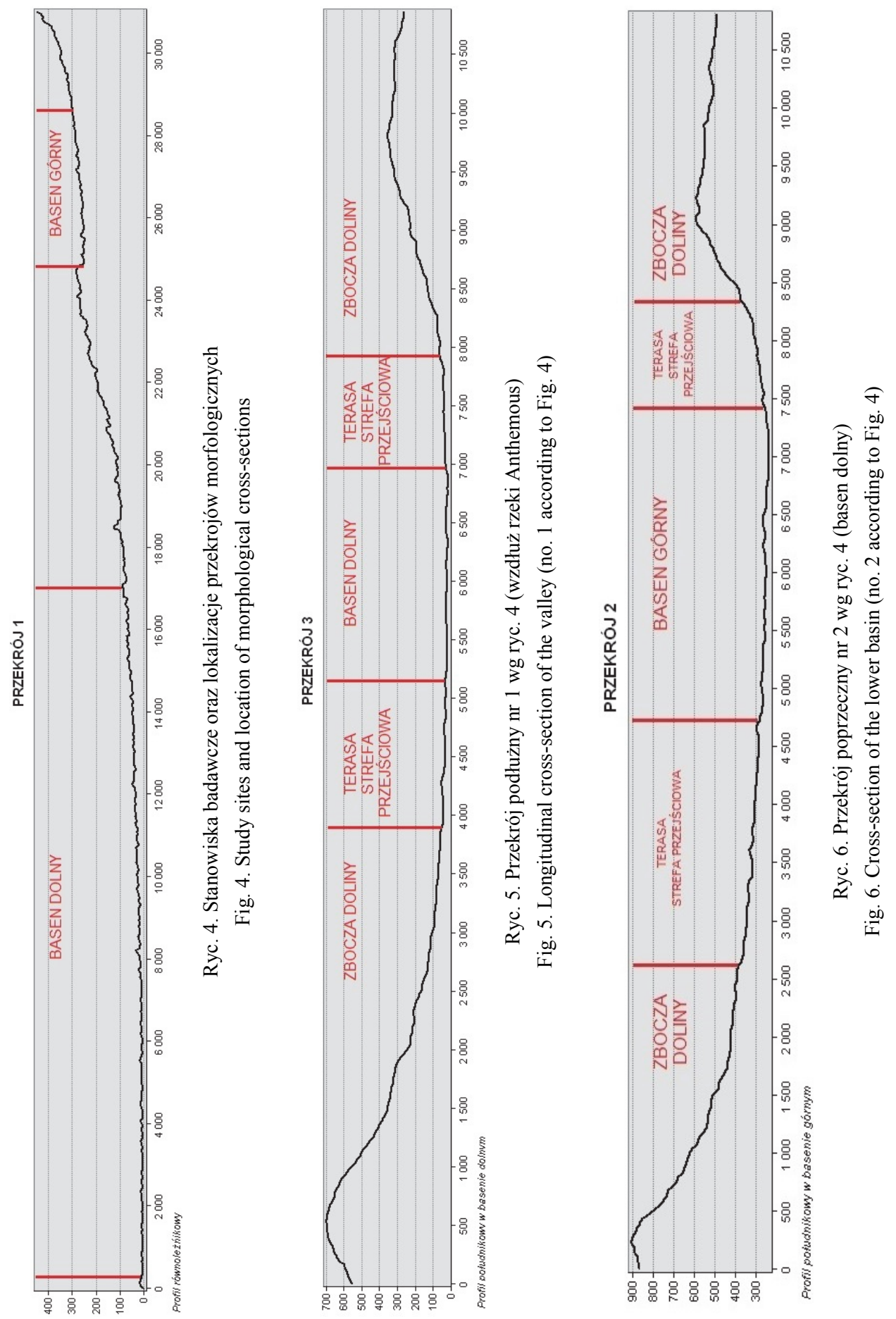


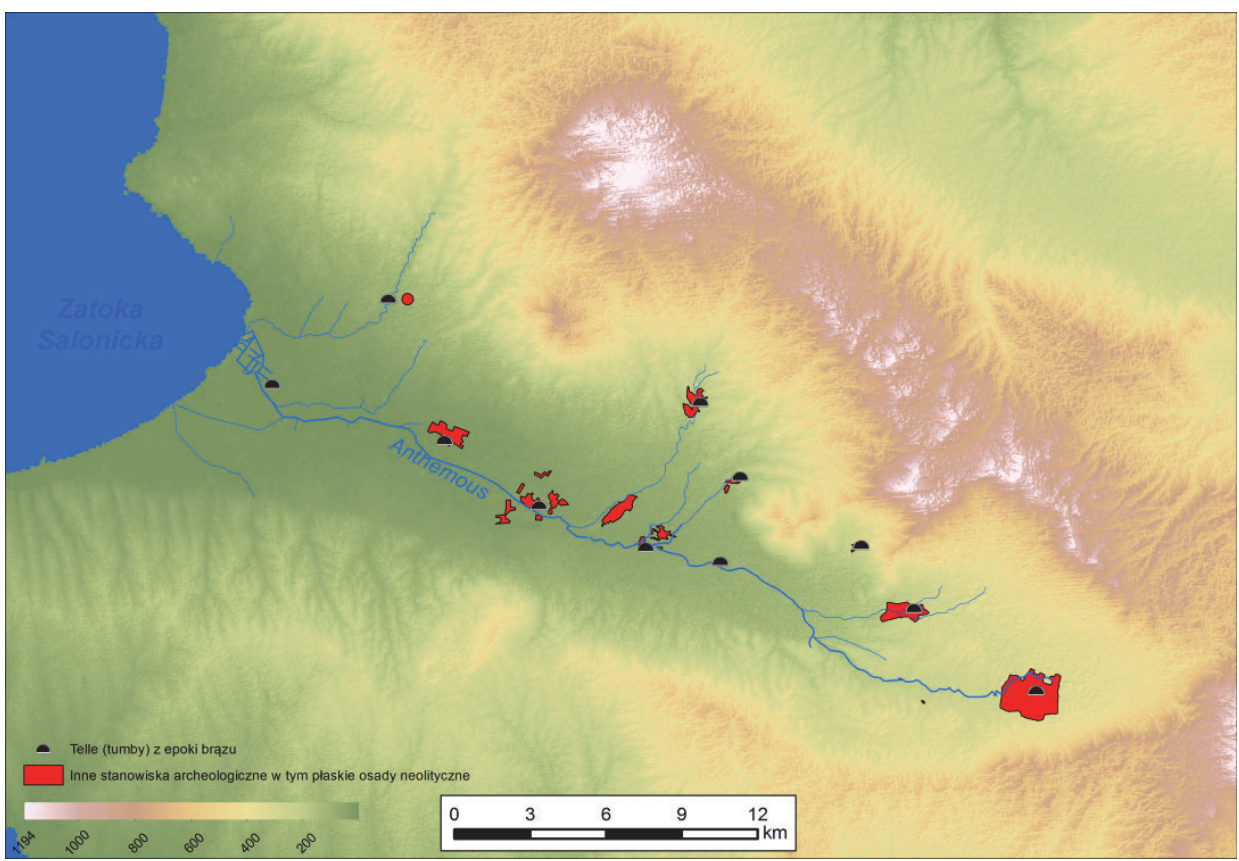

Ryc. 7. Przekrój morfologiczny nr 3 wg ryc. 4 (basen górny)

Fig. 7. Cross-section of the upper basin (no. 3 according to Fig. 4)

Większość z nich jest również epizodyczna. W okresach intensywnych opadów cieki te charakteryzują się krótkookresowymi, dużymi przepływami.

Roślinność w najniższych częściach doliny jest obecnie zdominowana przez gatunki uprawne. Jednak $\mathrm{w}$ górnych partiach doliny niektóre naturalnie występujące gatunki przetrwały w ,refugiach" i nie uległy przekształceniom związanym z intensywnym wypasem zwierząt, tworząc typową dla regionów śródziemnomorskich makię.

\section{Kontekst archeologiczny}

Jak wspomniano wcześniej, dowody na początki osadnictwa pochodzą z późnej fazy środkowego neolitu, ok. 7500 BP (Andreou i in. 2001, s. 299). W przeciwieństwie do epoki brązu okres neolitu reprezentowany jest w postaci rozległych i otwartych stanowisk osadniczych. Zalicza się do nich m.in. jedna z największych jak dotąd rozpoznanych osad neolitycznych w Kyparissi o powierzchni ok. 18 ha (Kotsakis 1999, s. 67; Andreou i in. 2016, s. 288). Z początkiem epoki brązu (5300-3100 BP, Andreou i in. 2001, s. 260) pojawia się osadnictwo tellowe, znane w północnej Grecji pod nazwą tumb. Są to antropogeniczne wzniesienia o kształcie ściętego stożka, nierzadko sięgające kilkunastu metrów wysokości i przeszło 100 metrów średnicy. 


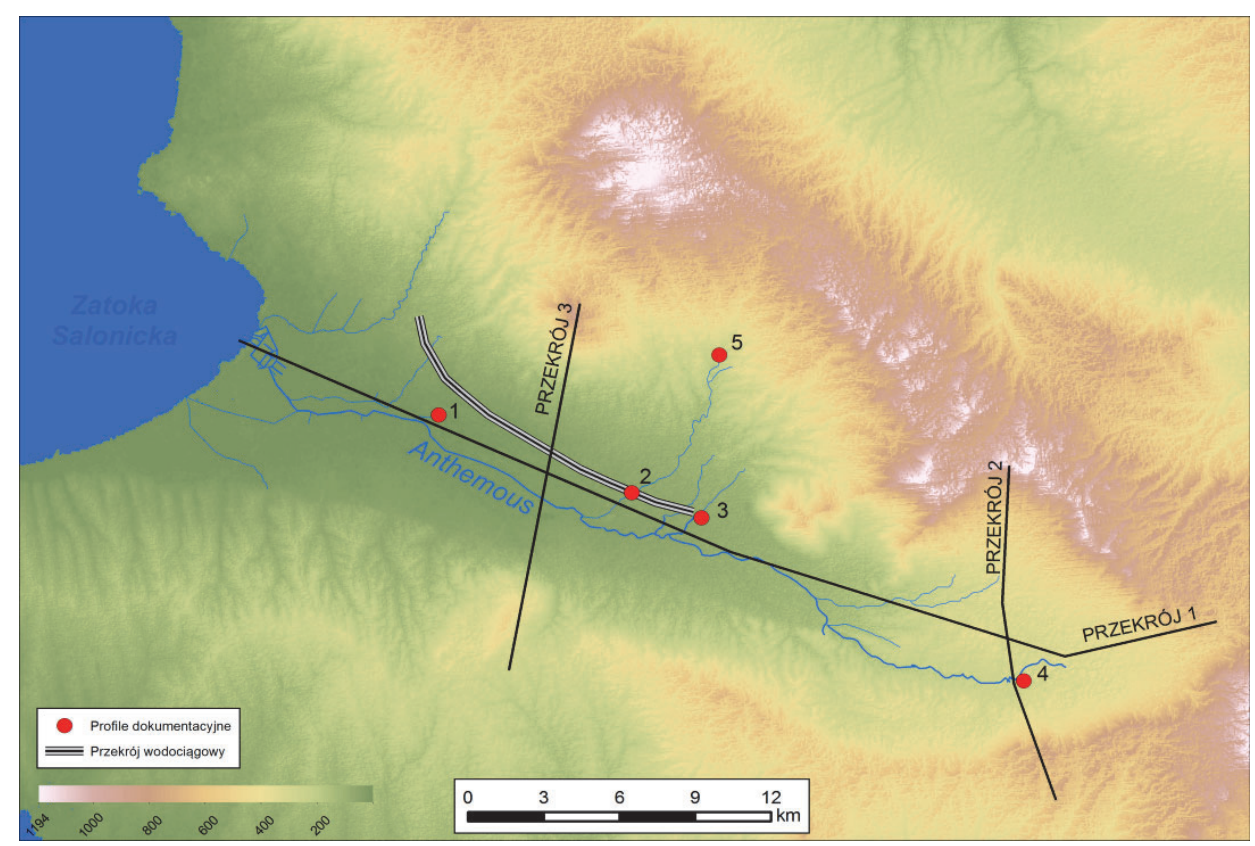

Ryc. 8. Stanowiska archeologiczne w dolinie Anthemousa

Fig. 8. Archaeological sites in the Anthemous river valley

Są one pozostałością stabilnego osadnictwa, które w wyniku czynników kulturowych powtarzało zabudowę mieszkalną w tym samym miejscu, na przestrzeni ponad tysiąca lat, podnosząc w ten sposób powierzchnię terenu (Rosenstock 2005). Obecnie $\mathrm{w}$ dolinie rozpoznanych jest 13 tego typu pozostałości osadniczych (ryc. 8) i związane są one głównie z basenem dolnym i górnym doliny. Stanowiska z tej epoki tworzą wyraźną koncentrację na tle centralnej Maecdonii (Andreou i in. 2016, s. 290) Wraz z nastaniem wczesnej epoki żelaza (3100-2500 BP), w regionie ludzkie osiedla koncentrowały się na tzw. stołach (trapezach), które stanowiły naturalne wyniesienia, zmodyfikowane przez człowieka m.in. wzmacnianiem stoków przez tworzenie teras. Są one o wiele większe od tumb i prawdopodobnie miały związek $\mathrm{z}$ rosnąca populacją i potrzebą większej przestrzeni.

\section{PALEOGEOGRAFIA}

\section{Transgresja morska}

Północna Grecja od maksimum ostatniego glacjału do przełomu er doświadczyła znaczących przekształceń linii brzegowej (van Andel i in. 1982). Po 21000 BP, w związku z ocieplaniem się klimatu, poziom oceanu światowego ulegał wzrostowi, 
co widoczne jest również w przypadku północnej części Morza Egejskiego (Runnels 2001, s. 253). Obliczony poziom wód dla tego akwenu dla maksimum ostatniego zlodowacenia to około $160 \mathrm{~m}$ poniżej obecnego stanu (van Andel i in. 1982). W tym czasie Zatoka Termajska nie istniała, a na jej miejscu rozciągały się rozległe równiny porośnięte roślinnością stepową (Krathopolou 2010). W związku z tym przypuszcza się, że większość stanowisk archeologicznych związanych z tym okresem znajduje się obecnie na dnie morskim. Tłumaczy to znikomą ilość późno- i schyłkowopaleolitycznego zapisu archeologicznego, obserwowanego na powierzchni lądu (Runnels 2001, s. 253). Obecnie główne znaleziska związane są z jaskiniami (badania geoarcheologiczne epipaleolitycznego stanowiska jaskiniowego z Beocji «patrz: Goslar, Kalicki i in. 2016»).

W ramach wzrostu średnich temperatur rocznych, w miarę zbliżania się do optimum holoceńskiego poziom morza w północnej Grecji podnosił się, by osiągnąć przybliżony stan dzisiejszy około 6000 BP (Ghilardi i in. 2008). Niemniej opisana tendencja jest rozpatrywana holistycznie dla generalnych trendów zmian linii brzegowej. Pewne odstępstwa od nich pokazują badania regionalne dotyczące tworzenia się i przekształceń Równiny Salonickiej. Na podstawie badań nad tym regionem scharakteryzowano silne procesy progradacji związane ze zdolnością transportową i depozycyjną rzek Wardar (Axios), Aliakmon i Loudiamos, które wypełniały stopniowo osadami płytką zatokę powstałą ok. 8000 BP. Dowody zmian linii brzegowej są widoczne także w kontekście stanowisk archeologicznych i ich opracowań środowiskowych. Dla przykładu neolityczna osada Nea Nikomedeia w okresie swojego trwania znajdowała się nad brzegiem morza (Bintliff 1976), natomiast obecnie znajduje się około $40 \mathrm{~km}$ od zatoki. Podobną sytuację odnotować można na stanowisku z epoki brązu - Kastanas, które w swoim czasie znajdowało się najprawdopodobniej na wyspie (Andreou i in. 2001, s. 298). Istnieje cały szereg dowodów archeologicznych na fluktuację zasięgu morza $\mathrm{w}$ tym regionie. Jednym $\mathrm{z}$ najdonioślejszych i potwierdzonych w źródłach historycznych jest przykład stolicy Imperium Macedońskiego - Pelli. Pella w trakcie panowania króla Filipa II czy Aleksandra Wielkiego była miastem portowym, do którego przez płytką zatokę o zmiennym zasoleniu dobijały okręty kupieckie i wojenne z Morza Egejskiego (Ghilardi i in. 2010). Morze Egejskie znajduje się aktualnie około $40 \mathrm{~km}$ od Pelli, co świadczy o rozmiarach regresji.

Dolina Anthemousa położona jest po wschodniej stronie Zatoki Termajskiej, lecz nie ma bezpośrednich dowodów na to, aby w przeszłości Anthemous również wpływał na zmiany linii brzegowej. Niemniej jest wysoce prawdopodobne, że mogły zachodzić pewne zmiany w bliskim sąsiedztwie obecnego wybrzeża. Jednym z dowodów na zmiany linii brzegowej są wyniki wykopalisk na stanowisku Gona, przeprowadzonych przez L. Reya (1917), w których stwierdza on istnienie osady palafitowej z epoki brązu. Stanowisko to obecnie znajduje się około $1,5 \mathrm{~km}$ od linii brzegowej. Istniejące mapy geologiczne obszaru wskazują, że strefa deltowa w doli- 
nie może zawierać osady pochodzenia morskiego. Do tej pory jednak nie zostały wykonane głębsze wiercenia, które mogłyby udokumentować występowanie sedymentacji morskiej, która świadczyłaby o diametralnych zmianach linii brzegowej. Planowane jest wykonanie wierceń w sąsiedztwie stanowiska Gona w 2016 r., w celu uchwycenia zmian warunków z morskich na lądowe.

\section{Szata roślinna}

Brak środowisk sedymentacyjnych i osadów, dzięki którym można byłoby odtworzyć historię roślinności dla doliny Anthemousa, uniemożliwia dokładne nakreślenie kierunków i dynamiki zmian. Niemniej istnieje szereg dokładnie opracowanych profili palinologicznych, które pozyskano w Macedonii w sąsiedztwie doliny. Dzięki temu można odtworzyć zgeneralizowany model rozwoju szaty roślinnej tego obszaru przez porównanie danych ze zbliżonych obszarów fizjogeograficznych.

Jak wspomniano wcześniej, okres schyłku plejstocenu charakteryzował się dominacją roślinności stepowej i otwartego krajobrazu, z największym udziałem Artemisia i Chenopodiaceae (Krathopolou 2010). Mimo ówczesnych uwarunkowań klimatycznych, które cechowała niska temperatura i relatywnie niska wilgotność powietrza, niektóre rodzaje zbiorowisk leśnych przetrwały w refugiach w wyższych partiach terenu (Bottema 1974; Willis 1994). Stało się to dzięki odcięciu tego obszaru od napływu zimnych i suchych mas powietrza z rejonów zlodowaconych przez barierę masywu Epiru i Rodopów (Gerasimidis et al. 2009, s. 32). Około 10000 BP wraz z ocieplaniem się klimatu nastąpiła ekspansja Quercus, który ok. 8000 BP dominował w zespołach leśnych pokrywających rozległe obszary Grecji północnej. Były to otwarte, świetliste lasy, o czym świadczą heliofilne gatunki, tj. Pistacia czy Sanguisorba (Willis 1992). Wartym odnotowania jest brak, obserwowanego w diagramach palinologicznych, znaczącego wpływu działalności ludzkiej na pokrywę leśną wraz z pojawieniem się w Grecji pierwszych rolników (ok. VIII tysiąclecia BP). Od około $9000 \mathrm{BP}$ w obszarach górskich nastąpiła ekspansja Pinus i Abies, których udział od 5000 BP uległ zmniejszeniu na rzecz Fagus. Obszary nizinne zdominowane przez dąb podlegały zmianie około $8000 \mathrm{BP}$. Od tego czasu zwiększał się udział Tilia, Ulmus czy Carpinus.

Pierwsze dowody na wyraźną antropogeniczną deforestację datowane są na połowę V tysiąclecia BP wraz z pojawieniem się w zapisie pyłkowym gatunków wskazujących na otwarty krajobraz (Cerealia, Plantago, Xanthium). Sytuacja ta powtarza się w większości profili palinologicznych na lądzie greckim (Krathopolou 2010). Od tego okresu zespoły leśne nie powróciły już do swojego poprzedniego zasięgu i składu.

Biorąc pod uwagę powyższe dane, wydaje się możliwe przeniesienie tego modelu na obszar doliny Anthemountasu. Ponadto w toku prac polowych w 2015 r. udało 
się pozyskać rdzenie, w sąsiedztwie stanowiska archeologicznego w Nea Raedestos w dolnym basenie doliny, które zawierają pyłki roślin. Są one aktualnie poddawane analizom palinologicznym, a ich wyniki ukażą się wkrótce (Niebieszczański $\mathrm{i}$ in. 2016).

\section{Czwartorzędowe procesy tworzenia się krajobrazu}

W trakcie badań AVAP II zadokumentowano szereg stanowisk terenowych w celu oceny środowisk sedymentacyjnych w zapisie kopalnym (ryc. 4). Większość $\mathrm{z}$ nich znajduje się $\mathrm{w}$ obrębie dna doliny, jednak niektóre lokują się w wyższych partiach, dzięki czemu rozpoznano różne środowiska sedymentacyjne. W głównej mierze były to profile, które nierzadko przekraczały kilkanaście metrów wysokości i występowały w miejscach erozyjnych podcięć stoków z czwartorzędową pokrywą zwietrzelinową przez rzekę. Ponadto, poza wspomnianymi profilami podcięć erozyjnych, zadokumentowano odkrywki związane z budową wodociągu między miejscowościami Thermi a Vasilika, w dolnym basenie doliny. Długość przekroju wynosiła około $8 \mathrm{~km}$ (ryc. 4), a maksymalne głębokości nie przekraczały $5 \mathrm{~m}$.

Obszary położone nisko, bo do $100 \mathrm{~m}$ n.p.m., charakteryzują się prawie wyłącznie sedymentacją fluwialną, głównie związaną z sedymentacją wystąpień pozakorytowych. Jak dotąd nie jest znana sekwencja poszczególnych epizodów powodziowych, w trakcie których materiał był deponowany. Niemniej widoczna jest pewna dynamika procesów hydrologicznych. W wielu profilach w ramach profilu wodociągowego natrafiono w osadach pozakorytowych, złożonych głównie z glin (ryc. 9), na wkładki gruboziarnistych aluwiów korytowych - piaski i żwiry (ryc. 10). Interpretowane są one jako kopalne koryta Anthemousa lub jego dopływów. Miąższość tych włożeń miejscami dochodziła nawet do $2,5 \mathrm{~m}$. Charakteryzują się one horyzontalnym położeniem dłuższych osi frakcji żwirowej, a także sekwencją drobnienia osadów ku górze od frakcji żwirowej do drobnych piasków. Podobnych struktur zadokumentowano kilkanaście wzdłuż całej linii przekopu wodociągowego, na długości $8 \mathrm{~km}$. Jest to zapis procesów erozyjno-akumulacyjnych w dolinach aluwialnych.

Erozja dominowała w wyższych partiach terenu. Profile pyłkowe dla północnej Grecji dokumentują znaczącą deforestację około 4500 BP, co powodować mogło uruchamianie procesów erozji na stokach i w efekcie zasypywanie koryt dopływów, jak i koryta rzeki Anthemous. Wykonane odwierty w niedalekim sąsiedztwie rzeki również wskazują na obecność wypełnień starorzeczy.

Miąższa pokrywa aluwialna pozwala na postawienie hipotezy, że część stanowisk osadniczych na dnie doliny mogła zostać przykryta tymi osadami. Przykładów dostarczają inne obszary północnej Grecji, gdzie istnieje cały szereg stanowisk pogrzebanych przez aluwia, co zyskało w literaturze miano terminu buried archaeology (Krahtopolou 2010). Podczas dokumentowania wykopów wodociągowych w dolinie 


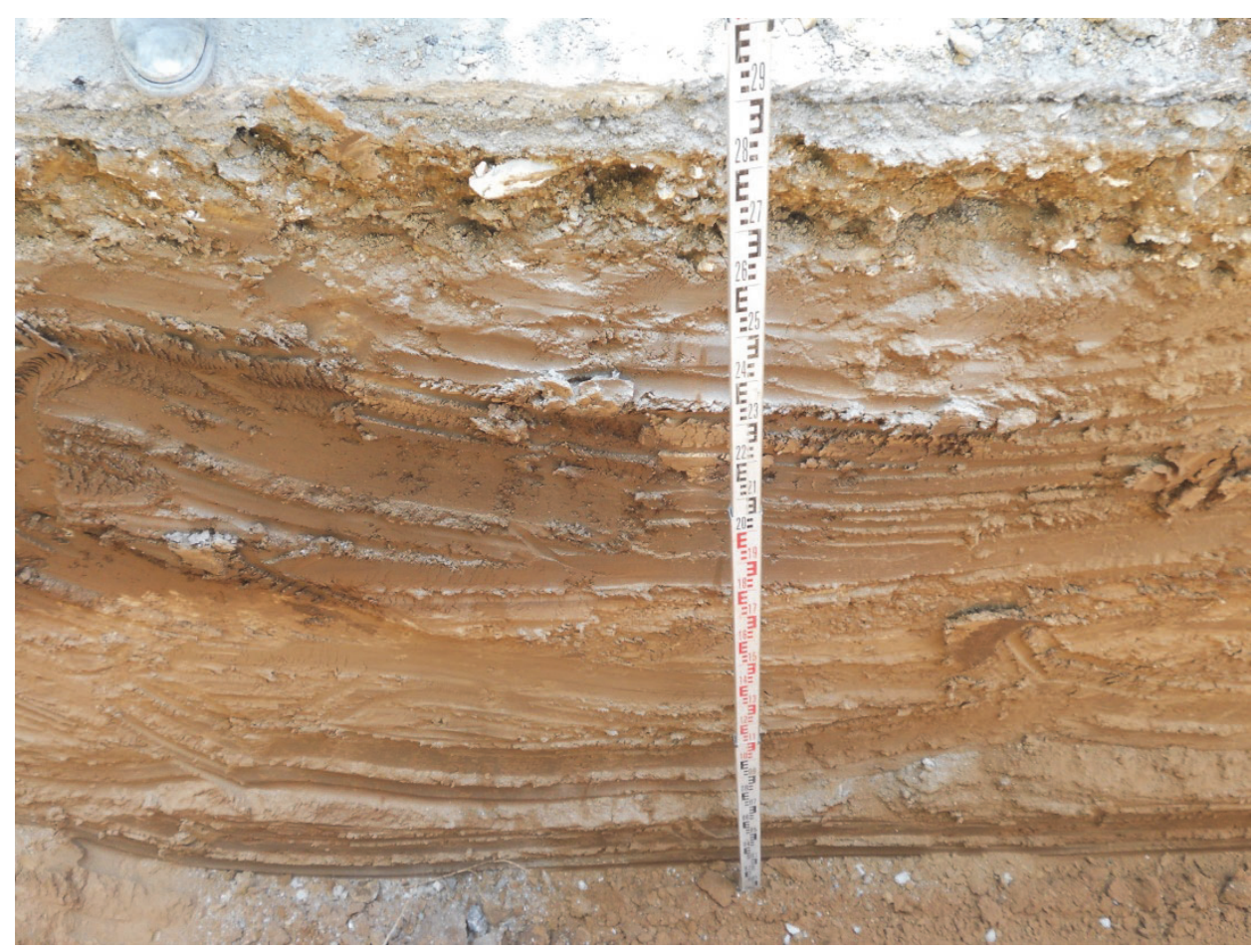

Ryc. 9. Zadokumentowany profil w przekopie wodociągowym. Osady depozycji pozakorytowej

Fig. 9. Documented profile in the water pipeline trench. Overbank sedimentation

Anthemousa natrafiono na materiał archeologiczny, z którego najstarsze fragmenty ceramiki datować można na późną epokę brązu (4500-3100 BP). Interpretować można te materiały jako określające datę post quem procesów agradacyjnych depozycji pozakorytowej. Niemniej obecny stan badań uniemożliwia wskazanie poszczególnych sekwencji czasowych powodzi w ramach analizowanych profili. Ponadto warto zaznaczyć, że nie natrafiono $w$ tych osadach na nadający się do datowania metodą radiowęglową materiał kopalny.

Profile ze wschodniej części dna doliny (stanowisko 4 wg ryc. 4), położnej na wysokości 200-400 m n.p.m. różnią się znacząco od opisywanych wcześniej. Odsłonięcie rzeczne nieopodal miejscowości Galatista ma około $12 \mathrm{~m}$ wysokości (ryc. 11) i zawiera utwory o różnym uziarnieniu i genezie. Najniższa część profilu zbudowana jest z mocno skonsolidowanych glin o czerwonym kolorze, z licznymi konkrecjami węglanowymi. Informacje dotyczące zapisu kopalnych środowisk sedymentacyjnych w Grecji północnej pozwalają na zaklasyfikowanie tego osadu jako plejstoceńskiego, który wytworzył się w suchym i zimnym klimacie. Wyraźnie zauważalna jest granica między utworami plejstoceńskimi a holoceńskimi. Te ostatnie 


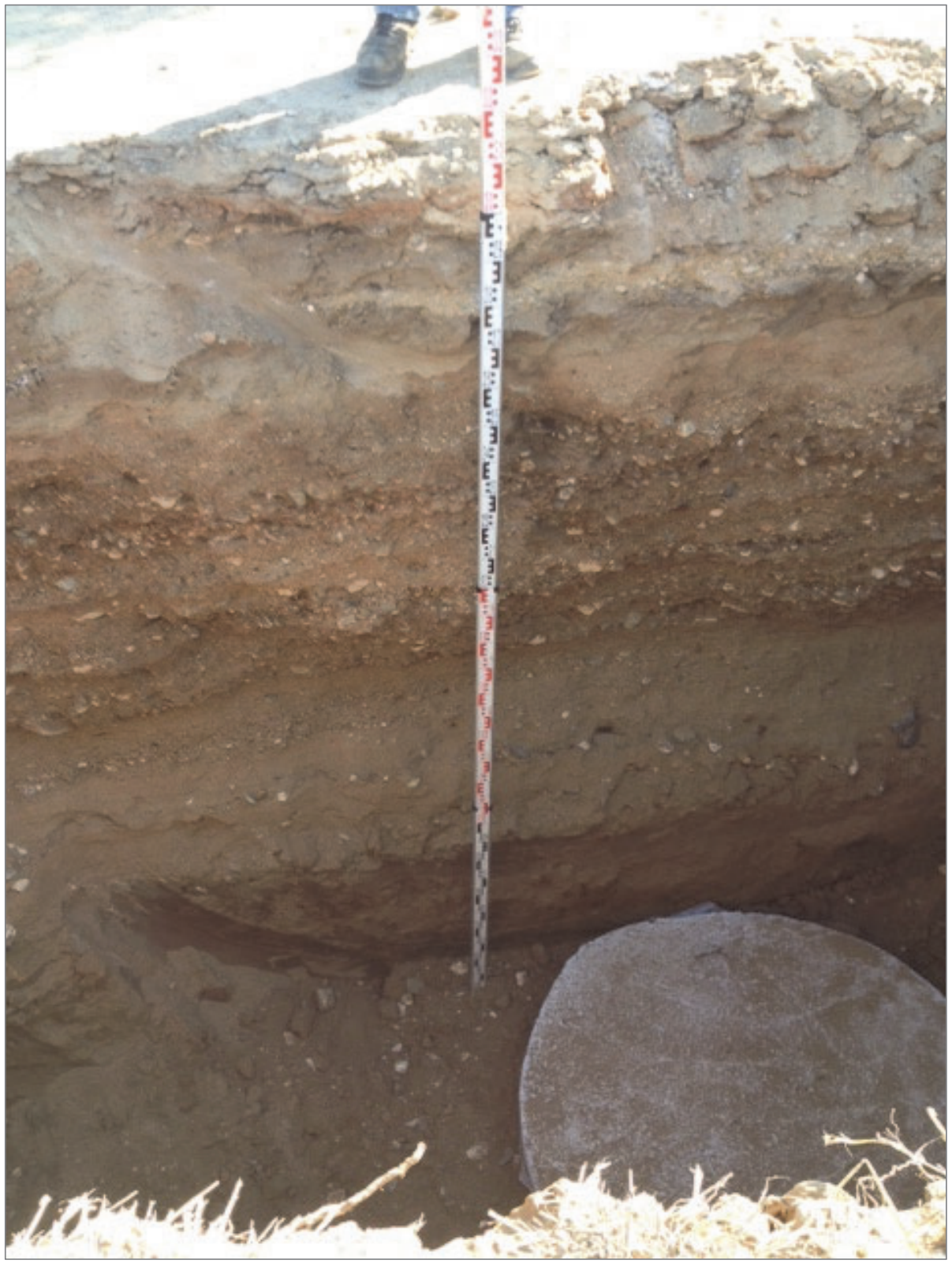

Ryc. 10. Zadokumentowany profil w przekopie wodociągowym. Osady starorzecza. Wyższa część profile prezentuje sedymentację fluwialną serii pozakorytowej. Poniżej zalegają grubsze osady zdeponowane w aktywnym korycie. W spągu znajduje się warstwa czerwonych glin, które wiązać można z okresem plejstoceńskim

Fig. 10. Documented profile in the water pipeline trench. Abandoned channel fill sediments. Legend: The upper part of the profile consists of fluvial sedimentation, underneath a coarser sediments represents the torrential deposits. Below lies a layer of red clays of probable the Pleistocene age 


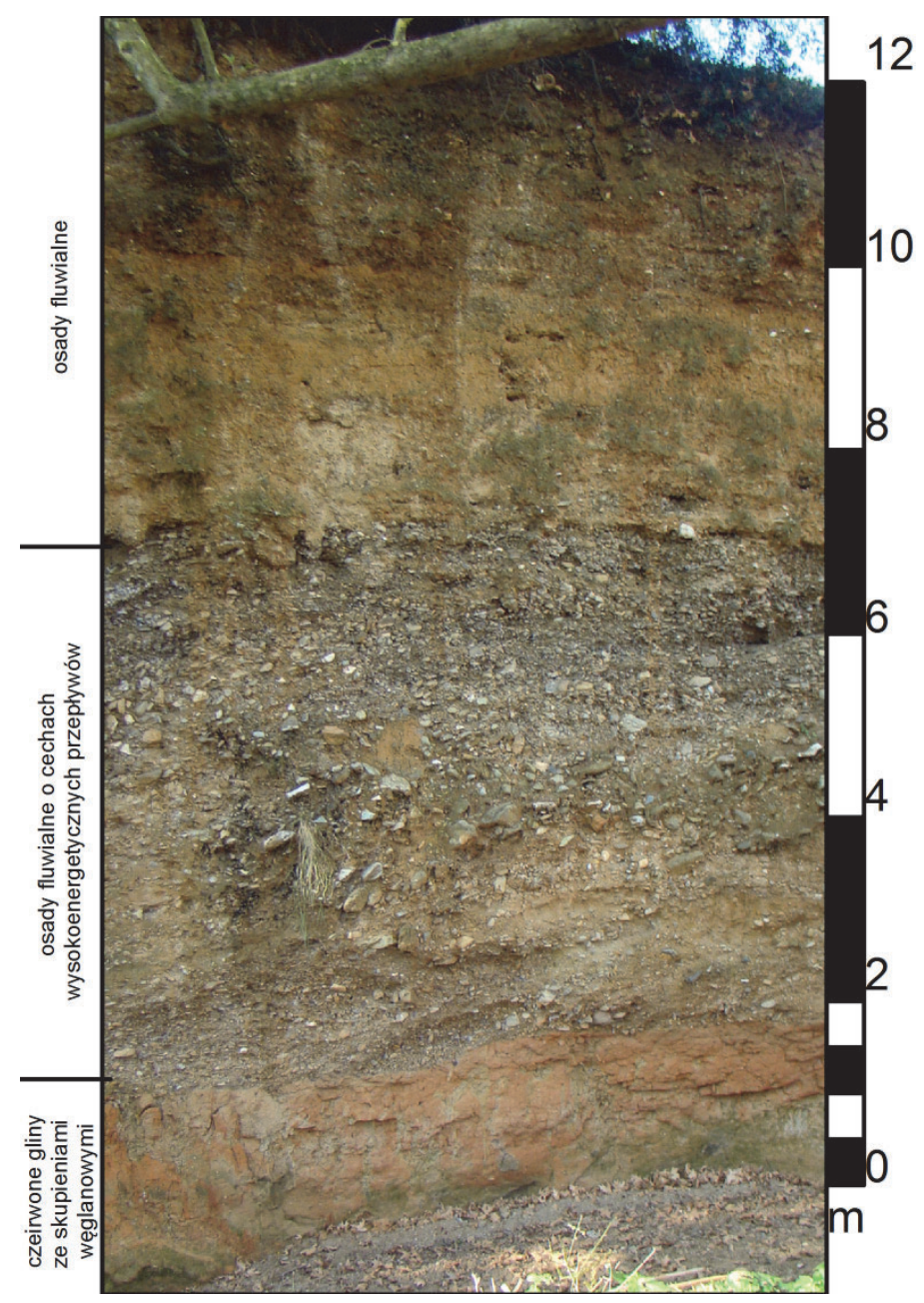

Ryc. 11. Profil nr 4 wg ryc. 4

Fig. 11. Profile no. 4 according to Fig. 4

charakteryzuje różnorodna sedymentacja i brak czerwonych glin. Dno doliny w tej części staje się o wiele węższe niż przy ujściu, dlatego też w profilach przeważa materiał deluwialny. Są to osady pylaste i piaszczyste, zawierające też większe, nieobtoczone okruchy. Lokalnie występują jednak wkładki z wyraźną kierunkowością żwirów i otoczaków, co sugeruje przepływy wodne (ryc. 12). Brak sekwencji uziarnienia w ich obrębie, struktura masywna oraz wielkość klastów wskazuje na krótkotrwałe, nagłe przepływy i dużą siłę transportową. Najwyższa część profilu (ostatni metr) zbudowana jest z osadów drobnych (ilastych, pylastych i piaszczystych), świadczących o spokojnie zachodzących procesach fluwialnych i denudacyjnych. 


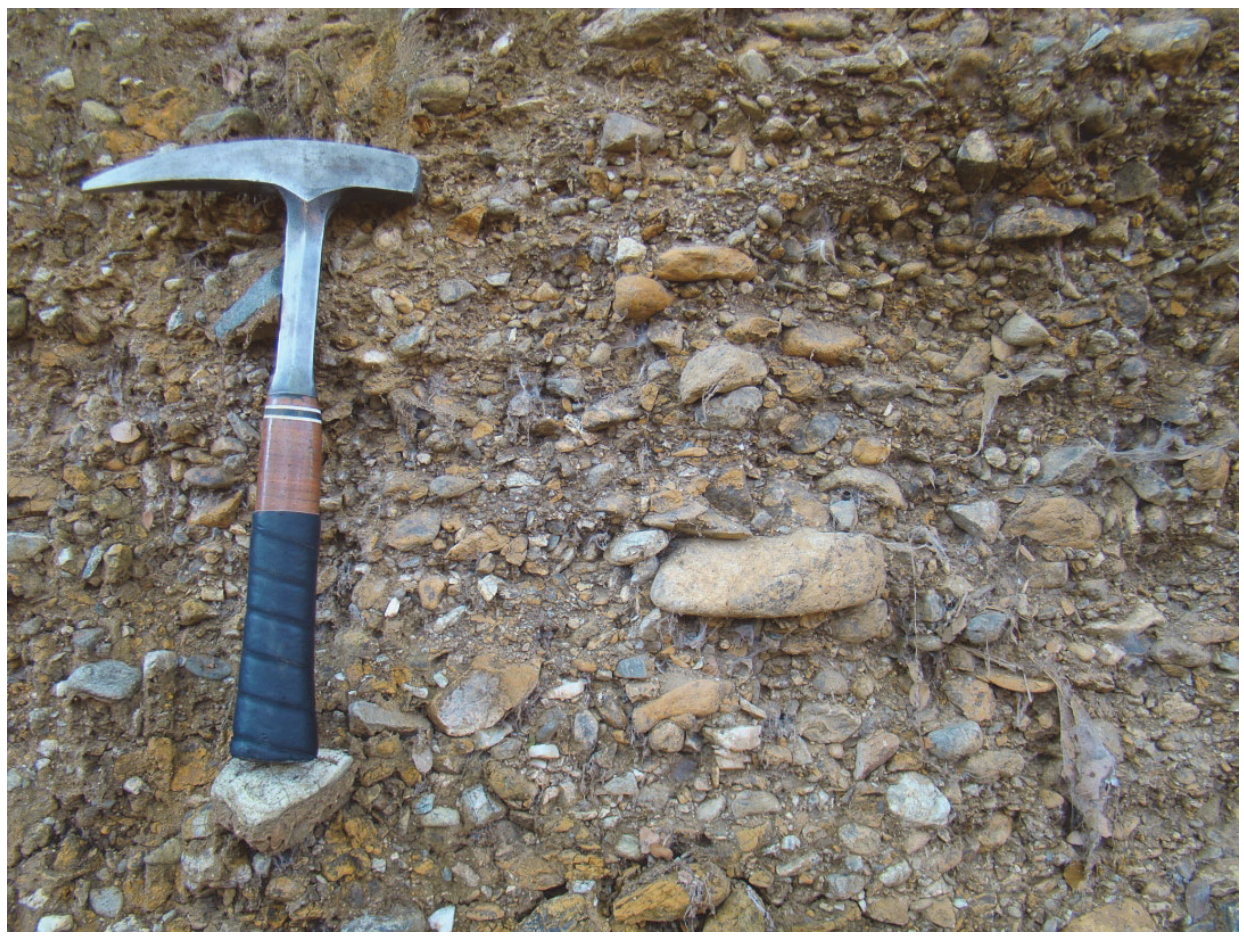

Ryc. 12. Kierunkowe ułożenie grubszych frakcji w profilu nr 4 (wg ryc. 4)

Fig. 12. Gravels and stones oriented horizontally due to the flow direction in profile 4 (according to Fig. 4)

Procesy, które miały miejsce w regionach górzystych, są widoczne wokół stanowiska archeologicznego Amalara, położonego na ok. 500 m n.p.m. na północnych zboczach doliny (stanowisko 5 wg ryc. 4). Rejon ten charakteryzuje się dużymi deniwelacjami. Miąższość pokrywy glebowej na stokach nie przekracza kilkudziesięciu centymetrów, a miejscami jej brak. Występują tu licznie wąskie i głębokie rozcięcia erozyjne, dzięki czemu widoczne są odsłonięte ściany często przekraczające $10 \mathrm{~m}$ wysokości. Żaden $\mathrm{z}$ tych profili nie zawiera w spągu plejstoceńskich, czerwonych glin. Materiał budujący te ściany jest w wysokim stopniu przemieszany i nie da się rozróżnić poszczególnych etapów depozycji. Zauważalne są wielkie głazy wystające ze ścian profilu o nieregularnych zarysach przekraczających nawet kilka metrów średnicy. Podobnie jest z drobniejszym materiałem, który nie wykazuje śladów obtoczenia. Depozycja tego materiału wiąże się z procesami erozyjnoakumulacyjnymi. W ich wyniku na obszarach o dużym spadku powstają głębokie rozcięcia erozyjne odsłaniające podłoże skalne.

W trakcie wykonywania prac AVAP II w sezonie 2014 zaobserwowano aktualnie oddziałujące procesy fluwialne i ich efekty. W przeciągu zaledwie dwóch dni 


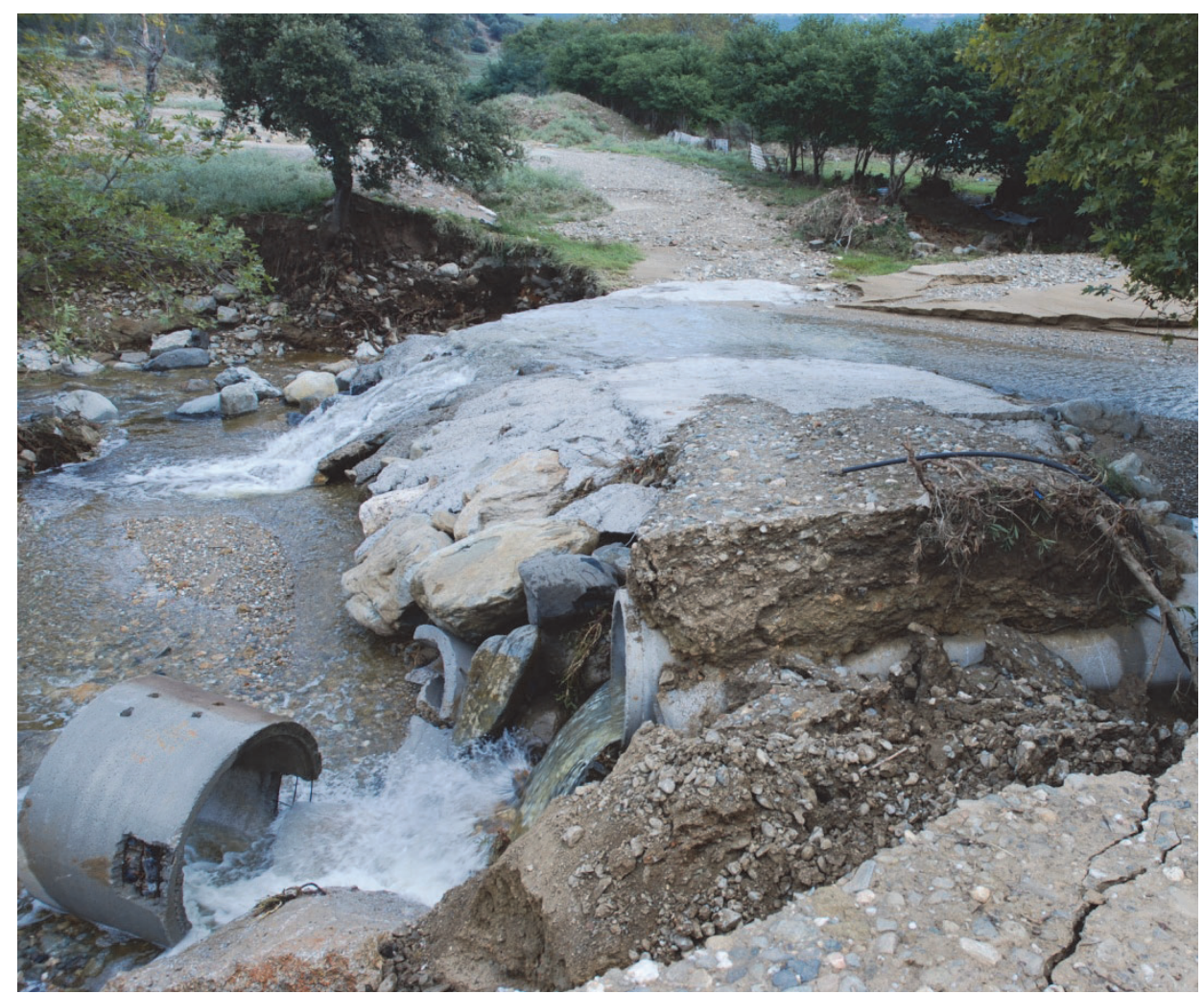

Ryc. 13. Zniszczona przez potok droga położona na zboczach doliny Anthemousa, nieopodal profilu 5 (wg ryc. 4)

Ryc. 13. Road destroyed by torrential flows on the valley slopes, near profile 5 (according to fig. 4)

silnych opadów, region stanowiska archeologicznego w Amalarze uległ znacznemu przekształceniu w niższych partiach. Ekstremalne przepływy rzeczne, jakie zostały uruchomione przez opady, zerwały betonowe drogi i stworzyły kilka świeżych odsłonięć ścian, sięgających miejscami 1,5 m wysokości (ryc. 13). Ponadto duży obszar został przykryty osadami fluwialnymi i koluwiami. Pierwsze charakteryzowały się pokrywą piaszczystą z widocznymi ripplemarkami, umiejscowionymi w odległości $20 \mathrm{~m}$ od przepływającego strumienia. Na zdolność transportową spływów gruzowo-błotnych wywołanych przez ulewę wskazują przemieszczenia dużych głazów o znanych pozycjach GPS, służących jako punkty reperowe do prac geodezyjnych. Niektóre z nich przemieściły się o kilkadziesiąt metrów i znalazły się w korycie strumienia. Skutkiem tych przepływów była również naruszona pokrywa roślinna. Były to m.in. powyrywane drzewa, ułożone koroną zgodnie z kierunkiem przepływu czy pogrzebana pod aluwiami roślinność niska. 


\section{WNIOSKI I PERSPEKTYWY}

Już sama wielkość obszaru doliny Anthemousa sugeruje zróżnicowanie środowisk sedymentacyjnych $\mathrm{w}$ jej obrębie. Ponadto region ten cechuje się zróżnicowanym tempem przemian środowiskowych w zależności od warunków geograficznych. Procesy agradacyjne miały przeważające znaczenie w tworzeniu się płaskiego dna doliny $\mathrm{w}$ sytuacjach powodziowych. W obrębie dolnego basenu funkcjonowała również dynamicznie zmieniająca się sieć hydrograficzna w postaci licznych dopływów rzeki Anthemous, które zostały pogrzebane osadami powodziowymi. W wyższych partiach doliny dominowały procesy erozyjne, którym towarzyszyły na stokach procesy erozji oraz ruchy masowe. Wyniki innych badań z obszaru północnej Grecji wskazują na podobny przebieg opisywanych procesów, różniących się tempem i intensywnością (Bintliff 1976; Krahtopolou 2010; Ghilardi et al. 2012: tam dalsza literatura). Na tym tle funkcjonowała sieć pradziejowych stanowisk archeologicznych, których część w wyniku działania powyższych procesów mogła zostać wyerodowana lub pogrzebana miąższymi pokrywami aluwialnymi.

Zmiana linii brzegowej na obecną chwilę pozostaje nierozwiązana, niemniej nie sposób wykluczyć jej możliwych fluktuacji, w świetle badań Równiny Salonickiej, w niedalekim sąsiedztwie (Ghilardi et al. 2008). Odwierty wykonane w 2016 r. dostarczyły materiału, który będzie badany pod tym właśnie kątem.

Ważnym elementem przyszłych badań jest datowanie i wyselekcjonowanie poszczególnych sekwencji depozycji powodziowej i kopalnych starorzeczy. Dostarczy to ważnej informacji dotyczącej tempa agradacji w dnie doliny, a także przebiegu procesów hydrologicznych na tym obszarze w przeszłości. Wszystkie te cele stawiane są w najbliższej perspektywie czasu przez AVAP II, który wraz z trwającym projektem archeologicznej prospekcji (AVAP I, AVAP III) ma na celu wieloaspektowe podejście do historii doliny Anthemousa zarówno pod kątem osadnictwa, jak i jego związku z procesami geomorfologicznymi i sedymentologicznymi.

W 2015 i 2016 r. zespół AVAP II przeprowadził kompleksowe rozpoznanie geoarcheologiczne stanowiska Nea Raedestos. Ich analiza dowiodła znacznych przekształceń krajobrazowych w sąsiedztwie stanowiska neolitycznego oraz z epoki brązu. Wyniki badań zostaną opublikowane wkrótce (Niebieszczański i. in 2016).

\section{Podziękowania}

Autor chciałby podziękować zespołowi badawczemu, bez którego realizacja powyższych prac nie byłaby możliwa. Przede wszystkim podziękowania kierowane są do Profesora Steliosa Andreou, Profesora Georgiosa Syridesa i Profesora Konstantinosa Vouvalidesa z Uniwersytetu Arystotelesa w Salonikach, Doktor Marii Pappa z Eforatu Regionu Salonik oraz Profesora Janusza Czebreszuka i Profesor 
Iwony Hildebrandt-Radke z Uniwersytetu im. Adama Mickiewicza w Poznaniu, którzy prowadzą projekt AVAP. Ponadto autor chciałby podziękować recenzentowi niniejszego artykułu za merytoryczne uwagi dotyczące tekstu, oprawy graficznej i materiałów kartograficznych.

\section{BIBLIOGRAFIA}

van Andel T., Schackleton J.C.

1982 Late Palaeolithic and Mesolithic coastlines of Greece and the Aegean. Journal of field archaeology, 9(4), s. 445-454.

Andreou S., Fotiadis. M., Kotsakis. K.

2001 The Neolithic and Bronze Age of Northern Greece. W: T. Cullen (red.), Aegean Prehistory. A Review (American Journal of Archaeology Supplement 1, s. 259-328). Boston: Archaological Institute of America.

Andreou S., Czebreszuk J., Pappa M., Niebieszczański J. (red.)

2016 The Anthemous Valley Archaeological Project. A Preliminary Results. Poznań: Wydawnictwo Naukowe UAM.

Bintliff J.

1976 The Plain of Western Macedonia and the Neolithic Site of Nea Nikomedeia. Proceedings of the Prehistoric Societies, 42, s. 241-262.

Bottema S.

1974 Late Quaternary vegetation history of Northwestern Greece. PhD thesis manuscript, Groeningen.

Kazakis N., Voudouris K., Vargemezis G., Pavlou Th.

2013 Hydrogeological regime and groundwater occurrence in the Anthemountas river basin, North Greece. Bulletin of the Geological Society of Greece, 47.

Kockel F., Mollat H.

1978 Thermi Sheet. Geological Map 1:50 000. Publication Department of Geological Maps of I.G.M.R. during the year 1978.

French D.H.

1967 Index of prehistoric sites in Central Macedonia and catalogue of sherd material in the University of Thessaloniki. Athens.

Gerasimidis A., Panajiotidis S., Georgios F., Korakis G.

2009 Review of the Late Quternary Vegetation History of Epirus (NW Greece). Phytologia Balcanica, 15(1), Sofia, s. 29-37.

Ghilardi M., Kunesh S., Styllas M., Fouache E.

2008 Reconstruction of Mid-Holocene sedimentary environments in the central part of the Thessaloniki Plain (Greece), based on microfaunal identification, magnetic susceptibility and grain-size analyses. Geomorphology, 97, s. 617-630.

Ghilardi M., Abdelsalem G., Syrides G., Bloemendal J., Psomiadis D., Paraschou D., Kunesh S., Fouache E.

2010 Reconstruction of the landscape history around the remnant arch of the Khlidi Roman Bridge, Thessaloniki Plain, North Central Greece. Journal of Archaeological Science, 37, s. 2425-2440.

Ghilardi M., Psomiadis D., Cordier S., Delanghe-Sabatier D., Demory F., Hamidi F., Paraschou T., Dotsika E., Fouache E. 
2012 The impact of rapid early- to mid-Holocene palaeoenvironmental changes on Neolithic settlement at Nea Nikomedeia, Thessaloniki Plain, Greece. Quaternary International, 266, s. 47-61.

Goslar T., Kalicki T., Kaczanowska M., Kozłowski J.K.

2016 Stratigraphic sequence in trench A: Complex II, Layers 2-12 - from the Early Neolithic to the Palaeolithic. W: M. Kaczanowska, J. Kozłowski, A. Sampson (red.) The Sarakenos Cave at Akraephnion, Beotia, Greece. Vol. II - The Early Neolithic, the Mesolithic and the Final Palaeolithic (s. 18-30). Kraków: Polish Academy of Arts and Science.

Grammenos D., Besios M., Kotsos M.

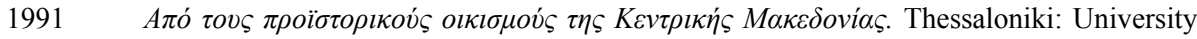
Press.

Heurtley W.A.

1939 Prehistoric Macedonia. An archaeological reconnaissance of Greek Macedonia in the Neolithic, Bronze and Early Iron Ages. Cambridge: University Press.

Krathopolou A.

2010 Geoarchaeology of Northern Pieria, Macedonia, Greece. Katerini: Mati Publications.

Kotsakis K.

1999 What tells can tell: Social space and settlement in the Greek Neolithic. W: P. Halstead (red.), Neolithic Society in Greece (s. 66-76). Sheffield: Academic Press.

Mountrakis D., Tranos M., Papazachos C., Thomaidou E., Karagianni E., Vamvarakis D.

2006 Neotectonic and seismological data concerning major active faults and stress regimes of Northern Greece. W: A. Robertson, D. Mountrakis (red), Tectonic development of the Eastern Mediterranean Region (s. 649-670). London: The Geological Society in London.

Niebieszczański J.

2016 Palaeogeography and sedimentary environments in the Anthemous Valley. W: P. Millitello, K. Żebrowska (red.), "Sympozjum Egejskie", Proceedings of "the $2^{\text {nd }}$ Students" Conference in Aegean Archaeology: Methods - Research - Perspectives. Syndesmoi 4. Universita Degli Studi di Catania: Catania, s. 89-100.

Niebieszczański J., Hildebrandt-Radke I., Vouvalidis K., Syrides G., Andreou S., Pappa M., Czebreszuk J.

2016 Geoarchaeological record of human activity reflected in fluvial and colluvial sediments in the Anthemous Valley (Greece). W: T. Kalicki, M. Frączek (red): Evolution of river valleys in Central Europe. Abstract Book (s. 80-82). Kielce: Jan Kochanowski University in Kielce.

Raspini F., Loupasakis C., Rozos D., Moretti S.

2013 Advanced interpretation of land subsidence by validating multi-interferometric SAR data: the case study of the Anthemountas basin (Northern Greece). Natural Hazards and Earth System Science, 13.

Rey L.

1917 Observations sur les premieres habitations de la Macédoine. Bulletin de Correspondance Hellénique, 41-3, Athens.

Rosenstock E.

2005 Hoyuk, Toumba and Mogila: a settlement form in Anatolia and the Balkans and its ecological determination 6500-5500 BC. W: E. Lichter (red.), How farming reached Europe? (s. 221-237, BYZAS 2). Istanbul: Ege Yayinlari, German Institute of Archaeology.

Runnels C.

2001 The Stone Age of Greece from the Palaeolithic to the Advent of the Neolithic. W: Cullen T. (red.), Aegean Prehistory. A Review (American Journal of Archaeology Supplement 1, s. 259-328), Boston: Archaeological Institute of America. 
Willis K.J.

1992 The Late Quaternary vegetational history of Northwestern Greece, 1. Gramoutsi Lake. New Phytologist 121(I), s. 101-117.

Willis K.J.

1994 The vegetational history of the Balkans. Quaternary Science Reviews, 13, s. 769-788.

Zervopolou A., Chatzipetros A., Tsiokos L., Syrides G., Pavlides S.

2007 Non-seismic surface faulting: the Peraia Fault case study (Thessaloniki, N. Greece). $4^{\text {th }}$ International Conference on Earthquake Geotechnical Engineering in 2007. Paper no. 1610 .

\section{AN OUTLINE OF SEDIMENTARY ENVIRONMENTS IN THE ANTHEMOUS VALLEY \\ (NORTHERN GREECE). PRELIMINARY RESULTS OF GEOARCHAEOLOGICAL RESEARCH UNDER THE ANTHEMOUS VALLEY ARCHAEOLOGICAL PROJECT}

\section{Summary}

This paper provides an overview of the first works under the Anthemous Valley Archaeological Project II.

The study area was settled by Prehistoric societies since the Middle Neolithic onwards. Since that time, the habitat changed several times, as evidenced by the geomorphological record. The sheer size of the valley is suggestive of a diversification of sedimentary environments. Moreover, the region shows the varying pace and magnitude of landscape changes. Alluviation processes were on-going in the Holocene as the flash floods occurred in the lower parts. Rapid flows carved the upland morphology while mass movements prevailed in the mountains, filling the river ravines with sediments. Geomorphological researches in other regions show that this is by no means incidental. However, the magnitude and proportion are different, and this issue is still pending further research. 